\title{
Drought and grazing: IV. blue grama and western wheatgrass
}

\author{
E.J. ENEBOE, B.F. SOWELL, R.K. HEITSCHMIDT, M.G. KARL AND M.R. HAFERKAMP ${ }^{1}$
}

\begin{abstract}
Authors are former graduate student and Associate Professor, Dept. of Animal and Range Sci. Mont. State Univ., Bozeman, Mont. 59715; Supervisory Rangeland Scientist, former Postdoctoral Rangeland Scientist, and Rangeland Scientist USDA-ARS, Fort Keogh Livestock and Range Research Laboratory, Rt. 1 Box 2021, Miles City, Mont. 59301.
\end{abstract}

\begin{abstract}
An understanding of the impacts of grazing during and following drought on rangeland ecosystems is critical for developing effective drought management strategies. This study was designed to examine the effects of drought and grazing on blue grama [Bouteloua gracilis (H.B.K) Lag. ex Griffiths] and western wheatgrass [Pascopyrum smithii Rydb. (Love)] tiller growth dynamics. Research was conducted from 1993 to 1996 at the Fort Keogh Livestock and Range Research Laboratory located near Miles City, Mont. An automated rainout shelter was used during 1994 to impose a severe late spring to early fall (May to October) drought on 6 of twelve, 5- x 10-m non-weighing lysimeters. Twice replicated grazing treatments were: 1) grazed both the year of (1994) and the year after (1995) drought; 2) grazed the year of and rested the year after drought; and 3 ) no grazing either year. Drought had minimal impact on tiller relative growth rates of plants grazed twice, although it reduced $(P \leq 0.01)$ rates of axillary tiller emergence for blue grama $(79 \%)$ and western wheatgrass $(91 \%)$, respectively. Defoliation periodically increased relative growth rates $(P \leq 0.05)$ and tiller emergence $(P \leq 0.01)$ of both species. Neither drought nor grazing affected tiller densities or tiller replacement rates of either species nor did they affect productivity of blue grama. Drought, however, reduced (P $\leq$ 0.01) productivity of western wheatgrass $50 \%$ in 1994 whereas grazing reduced productivity $(P \leq 0.01)$ by $46 \%$ in 1994 and $69 \%$ in 1995 . Moderate stocking levels $(40-50 \%$ utilization) during and after drought did not adversely affect the sustainability of these dominant native grasses.
\end{abstract}

Key Words: Bouteloua gracilis, Pascopyrum smithii, production, rainout shelter, rest, water potential

The Northern Great Plains support 7 million animal units (AUs) in the U.S. and Canada (USDA 1993, Willms and Jefferson 1993). Campbell (1936) stated that 2 or 3 years out of 10 would be drought years in the Northern Great Plains. Drought and grazing can affect plant productivity and decrease plant

This research was conducted under a cooperative agreement between USDA-ARS and the Montana Agric. Exp. Sta. Mention of a proprietary product does not constitute a guarantee or warranty of the product by USDA, Montana Agric. Exp. Sta., or the authors and does not imply its approval to the exclusion of other products that may also be suitable. USDA-Agricultural Research Service, Northern Plains Area, is an equal opportunity/affirmative action employer and all agency services are available without discrimination.

Manuscrip accepted 26 Mar. 01

\section{Resumen}

Un entendimiento de los impactos del apacentamiento durante y después de la sequía en los ecosistemas de pastizal es critico para desarrollar estrategias efectivas de manejo de la sequía. Este estudio se diseño para examinar los efectos de la sequía y el apacentamiento en al dinámica de crecimiento de los hijuelos de "Blue grama" [Bouteloua gracilis (H.B.K) Lag. ex Griffiths] y "Western wheatgrass" [Pascopyrum smithii Rydb. (Love)]. La investigación se condujo de 1993 a 1996 en el Laboratorio de Investigación de Ganado y Pastizales Fort Keogh cerca de Miles City, Mont. Durante 1994 se utilizo un protector de lluvia automatizado para aplicar una sequía severa de fines de primavera e inicios de otoño (Mayo a Octubre) en 6 de los 12 lisímetros de $5 \mathrm{x}$ $10 \mathrm{~m}$. Los tratamiento de apacentamiento se repitieron 2 veces $y$ fueron:1) apacentado en el año de la sequía (1994) y el año siguiente (1995), 2) apacentado el año de la sequía y descansado el año siguiente y 3) sin apacentamiento en ambos años. La sequía tuvo un impacto mínimo en las tasas relativas de crecimiento de los hijuelos de plantas apacentadas doble, aunque redujo $(P \leq$ 0.01) las tasas de emergencia de hijuelos auxiliares del "Blue grama" (79\%) y "Western wheatgrass" (91\%). La defoliación periódica incremento las tasas relativas de crecimiento $(P \leq 0.05)$ y la emergencia de hijuelos $(P<0.01)$ de ambas especies. Ni la sequía ni el apacentamiento afectaron las densidades de hijuelos o las tasas de remplazo de estos en ninguna de las especies, tampoco afectaron la productividad del "Blue grama". Sin embargo, la sequía redujo la productividad $(P \leq 0.01)$ de "Western wheatgrass", en $50 \%$ en 1994, mientras que el apacentamiento redujo la productividad $(P \leq 0.01)$ en $46 \%$ en 1994 y $69 \%$ en 1995 . Niveles moderados de carga (40-50\% de utilización) durante y después de la sequía no afectan adversamente la sustentabilidad de estos zacates nativos dominantes.

longevity (Ludlow 1986). Large portions of plant communities within the Northern Great Plains are dominated by blue grama (Bouteloua gracilis, [H.B.K] Lag. ex Griffiths) and western wheatgrass (Pascopyrum smithii, Rydb.). It is apparent that these 2 plant species have evolved with the combined effects of drought and herbivory. Therefore, it is important when managing rangelands to know how individual plants persist in the face of these stressors.

Many researchers have examined the role of tillers in plant survival (Richards et al. 1987, Olson and Richards 1988, Bullock et al. 1994, Zhang and Romo 1995), but quantitative studies on the 
impacts of grazing during and after drought on tiller population dynamics are lacking. It has been hypothesized that grazing during and following drought can suppress recovery rates of individual plants as well as plant communities (Pieper and Heitschmidt 1988, Burkhardt 1996). To test this hypothesis, we examined the effects of grazing during and after a growing season drought on xylem water potentials, tiller relative growth rates (RGR), seasonal axillary tiller emergence, annual tiller replacement, tiller densities, and aboveground net primary production (ANPP) of blue grama and western wheatgrass. Heitschmidt et al. (1999) have published effects of drought on soil water, vegetative productivity and plant species composition.

\section{Materials and Methods}

\section{Study Area}

This study was part of a large rainout shelter project conducted on the USDA, ARS Fort Keogh Livestock and Range Research Laboratory near Miles City, Mont. (46 $\left.{ }^{\circ} 19^{\prime} 45^{\prime} \mathrm{N} 105^{\circ} 49^{\prime} 45^{\prime} \mathrm{W}\right)$. This area is representative of the semi-arid mixed grass prairie of the Northern Great Plains. Native vegetation on the 22,500-ha research station is a grama-needlegrasswheatgrass (Bouteloua-Stipa-Agropyron) mix (Kuchler 1964). Long-term annual precipitation averages $34-\mathrm{cm}$ (NOAA 1996) with about $60-70 \%$ received during the mid-April through mid-September growing season (Fig 1). Temperatures may exceed $38^{\circ} \mathrm{C}$ during summer and decrease to $-40^{\circ} \mathrm{C}$ during winter. The average frost-free period is 150 days.

\section{Lysimeters and Treatments}

Twelve, 5- X 10-m non-weighing lysimeters were arranged perpendicularly to the slope along a $65-\mathrm{m}$ transect in 2 groups of 6 lysimeters with a 5-m area between groups within a grazing exclosure. An automated rainout shelter was constructed to control the amount of precipitation received on 1 of the 2 sets of 6 lysimeters. The 12- X 35-m metal framed "roof" was mounted on $15-\mathrm{cm}$ diameter plastic wheels atop seven, 5-cm wide rails stationed about $75-\mathrm{cm}$ above the soil surface. Rails extended from the top edge (i.e., upslope) to 15-m below the bottom edge of the lysimeters. Rails were located directly over lysimeter borders. The shelter was equipped with a moisture sensitive conductance plate that when wetted, activated a small electric motor and its associ-

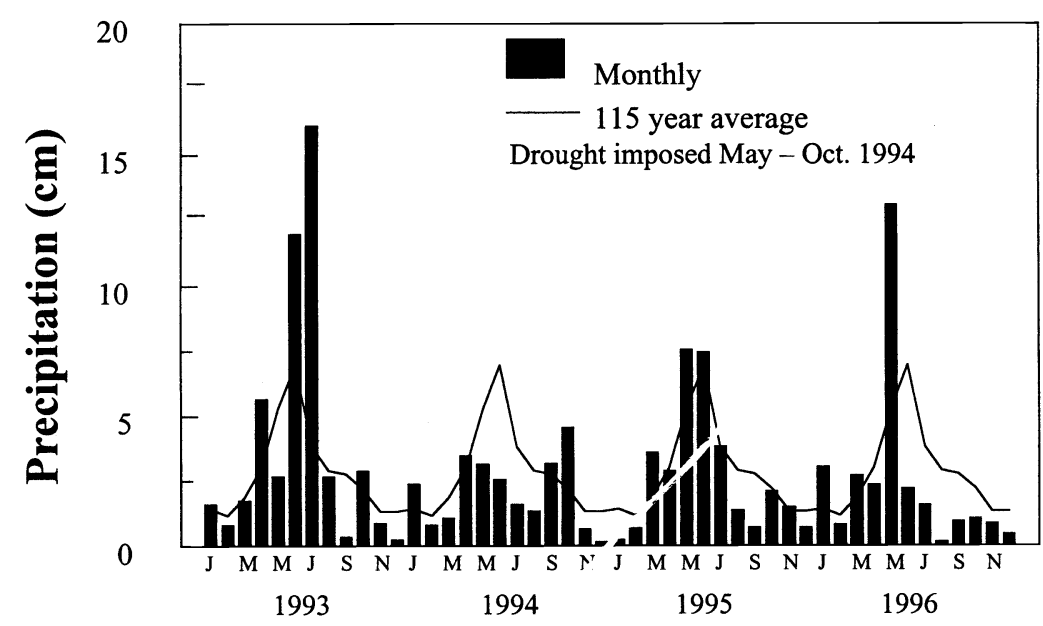

Fig. 1. Monthly precipitation (cm) from January 1993 through December 1996 and long-term (115 yr) average at Miles City, Mont. including the drought treatment in 1994 (NOAA 1996; Heitschmidt et al. 1999).

ated drive system, which moved the shelter across the lysimeters.

Following the 1993 pre-treatment baseline year, twice replicated treatments were: 1) grazed during the year of drought and rested the year after, hereafter referred to as G94; 2) grazed both the year of the simulated drought and the year after, hereafter referred to as the G94-95; and 3) rested in all years, hereafter referred to as the ungrazed treatment (UG). The same 3 treatments were repeated in the nondrought set of lysimeters. Lysimeters were grazed intensively with 6 ewes and their twin lambs for a few hours in early June and early July of both 1994 and 1995 to achieve $40-50 \%$ utilization. The simulated drought was imposed (1 growing season) from mid-May to early October 1994.

\section{Precipitation, Soil Water, and Xylem Water Potentials}

Precipitation was monitored on site using standard rain gauges (Heitschmidt et al. 1999). Soil water was estimated a minimum of once a month from April through October at depths of 15-, 30-, 60-, 90- and $120-\mathrm{cm}$ using a dielectric soil water probe (Heitschmidt et al. 1999).

Xylem water potentials of blue grama and western wheatgrass plans growing in the ungrazed drought and non-drought treatments were estimated on 7 dates between 18 May and 28 July, 1994 and 6 dates between 15 May and 2 August, 1995. Measurements were made at 0430 and 1230 hours on the youngest fully expanded leaves of individual plants using standard pressure chamber technqiues (Scholander et al. 1965). Sample plants were randomly selected along a transect within each lysimeter. Sample size per species/sample date/sample time/lysimeter was 1 in 1994 and 2 in 1995.

\section{Tiller and Production \\ Measurements}

Six permanent $14-\mathrm{x} 18$-cm quadrats per lysimeter were randomly established within mixed blue grama and western wheatgrass communities. Quadrat locations were restricted to areas not previously sampled, and at least $50-\mathrm{cm}$ inside the plot edge. Colored wire rings were used to permanently identify 10 study tillers per quadrat, 5 each of blue grama and western wheatgrass. The same quadrats were used for the duration of the research. If a marked tiller produced axillary tillers at anytime during the growing season, the axillary tillers were marked with a different color to distinguish them from primary tillers. Different tillers were marked in the same manner in 1995.

From an initial population of 360 tillers per species, repeated, season-long measurements ( $\mathrm{n}=17$ in $1994 ; \mathrm{n}=14$ in 1995) were taken on 270 blue grama and 329 western wheatgrass tillers in 1994 and 320 blue grama and 341 western wheatgrass tillers in 1995. Differences between marked and measured tillers were due to lost markers or excluding data from tillers which were not grazed twice. Tiller measurements began in mid-May and continued weekly through August with additional measurements for quantification of any autumn growth. Information gathered on an individual tiller during each visit included: plant height, phenology, number of leaves, axillary tillering and tiller senescence. 
Measuring tillers nondestructively prevented direct estimates of cumulative biomass through time. Height measurements were converted to biomass by developing hiehgt-weight relationships of tillers located on the same clayey range site in the near vincinity of the lysimeters. For each species, tillers were measured, clipped at the soil surface and bundled together with other tillers of the same height $(+/-1 \mathrm{~cm})$. Five bundles per species representing the range of heights for those tillers found in the lysimeters were collected before each grazing event. Individual bundles containing 5 western wheatgrass and 10 blue grama tillers were placed in plastic bags, transported to the laboratory and immediately cut into segments. Tiller bundles were cut from the base upward in segments of $1-\mathrm{cm}$ for blue grama and $3-\mathrm{cm}$ for western wheatgrass in a manner similar to Tusler (1993), so all height ranges of plants found in the lysimeters were represented. All segments were oven dried at $60^{\circ} \mathrm{C}$ for 48 hours before weighing.

Tiller relative growth rates $\left(\mathrm{g} \mathrm{g}^{-1}\right.$ day $\left.^{-1}\right)$ were calculated according to Radford (1967) as:

Tiller relative growth rates $=\left(\log _{\mathrm{e}} \mathrm{W}_{\mathrm{t}+1}-\mathrm{I}^{-1}\right.$

Density of western wheatgrass was determined by counting total number of live tillers within each quadrat. Because of the "mat-like" growth form of blue grama, density was determined by counting the number of tillers within a $5.75-\mathrm{cm}^{2}$ circular plot, or $2 \%$ of the quadrat area, randomly located within each permanent quadrat. Densities were measured on 24 May 1994, 1995, and 1996.

Standing crop inside 20 randomly located $250-\mathrm{cm}^{2}$ quadrats per lysimeter was harvested monthly by species from 1993 to 1996 (Heitschmidt et al. 1999). Samples were oven dried at $60^{\circ} \mathrm{C}$, separated into live and dead components and then weighed. Aboveground net primary production was calculated for blue grama and western wheatgrass by summing all positive increases in standing crop from April to November.

\section{Data Summarization and Analyses}

Soil water measurements were analyzed using repeated measures analysis of variance (AOV) with year, depth, treatments and dates in the model. Years and/or dates and all associated 2- and 3-way interactions were analyzed as within plot repeated measures and tested using full model residuals (Heitschmidt et al. 1999).

Pre-dawn and mid-day water potential data were analyzed separately using repeated measures $\mathrm{AOV}$ with drought treatment, plant species, and date as main effects. The error terms for testing the main effects of drought treatments were the replication by treatment interaction. The error terms for testing the main effects of species and the interaction effects of species and drought treatments were replication by treatment by species. The full model residuals were used to test the repeated measures effects of dates and all associate 2- and 3-way interaction effects.

Growth records were summarized using average tiller relative growth rate within 3 time periods. Time periods were: 1) the last 2 weeks of May before the first grazing event; and 3) July to October of 1994 and July to early September 1995 . The number of 1994 post-grazing sampling dates was 8 , but this was reduced to 4 in 1995 , as both species were essentialy dormant throughout both summer periods.

A univariate, repeated measures analysis of variance model was used to analyz data. A 2-way AOV was used to determine the effects of drought and grazing on percent tiller recruitment. Tiller relative growth rates and tiller recruitment are reported for tillers that were grazed twice, since the majority ( $\geq 85 \%$ ) of the tillers in the lysimeters were grazed during both grazing events. This was done to reduce confounding effects of combining once grazed and twice grazed tillers.

Tiller densities from May 1994 (i.e., pre-treatment) were included as a covariate in the 2 following years' data. Means were considered to be significantly different when $\mathrm{P} \leq 0.05$, unless noted otherwise. Individual lysimeters were considered experimental units for all analyses.

Heitschmidt et al. (1999) reported plant functional group and species compositional differences among treatment plots in 1993. We initially used the pre-treatment year (1993) blue grama and western wheatgrass productivity estimates as covariates in subsequent year analyses. Since the covariates were never significant $(P \geq 0.22)$, they were subsequently excluded from the final analyses.

Drought treatments might be considered pseudo-replicated, according to Hurlbert (1984), since the rainout shelter size and cost precluded classical treatment replication. The use of a single rainout shelter to test the effects of drought is common in the literature (Busso 1988, Busso et al. 1989, 1990, Frank and Ries 1990, NeSmith and Ritchie 1992, Busso and Richards 1993, 1995). Statistical tests used in our study were conservative, since the experimental units were not quadrats, indi- vidual plants or individual tillers. In addition, analyses were conducted in a manner similar to the first paper in this series (Heitschmidt et al. 1999).

\section{Results}

\section{Precipitation, Soil Water, and Water Stress}

In 1993, the pre-treatment year, total annual precipitation was $38 \%$ above the long-term average of $34-\mathrm{cm}$ (Fig. 1). Annual precipitation in 1994 was $24.7-\mathrm{cm}$, $24 \%$ below average. Precipitation from 1 May to 31 October 1994 was $16.3 \mathrm{~cm}$ compared to the $27.1-\mathrm{cm}$ average. Total annual precipitation for 1995 and 1996 was similar to the long-term average (Heitschmidt et al. 1999).

Heitschmidt et al. (1999) previously reported no differences in soil water dynamics between imposed 1994 drought and natural precipitation and grazing treatment lysimeters. The only significant main effects were year and date .

The drought treatment did not affect either pre-dawn or mid-day leaf water potential of either blue grama $(P=0.93)$ or western wheatgrass $(\mathrm{P}=0.40$; Table 1$)$. Water potentials were affected by plant species (midday; $P \geq 0.01)$, date $(P \geq 0.01)$ and their interaction $(P \geq 0.01)$. Date was the most important factor accounting for $85 \%$ of the total sum of squares for predawn and $58 \%$ for midday water potentials. Species accounted for less than $5 \%$ of the total sum of squares. The date effect followed anticipated seasonal trends of increasing water potentials with decreasing soil water content. The absence of significant drought treatment-by-date $(\mathrm{P} \geq$ 0.18 ) and drought treatment-by-date-byspecies $(P \geq 0.86)$ interactions showed that the magnitude of water stress was similar in both the drought and non-drought treatment plots during 1994 (i.e., the year of the imposed drought) as well as 1995.

\section{Utilization}

Ninety-eight percent of marked blue grama tillers (265 of 270) in 1994, and $97 \%$ (309 of 320) in 1995 remained in a vegetative phenological stage. On average, utilization was $39 \%$ and $47 \%$ on blue grama tillers for the first and second grazing events in 1994, and $23 \%$ and $45 \%$ for the first and second grazing events in 1995. Over $85 \%$ of the marked blue grama tillers in the grazed lysimeters were grazed twice in both years.

Ninety-eight percent (323 of 329) in 
Table 1. Predawn and midday leaf water potentials (MPa) for western wheatgrass (Pasm) and blue grama (Bogr) plants growing in drought and nondrought ${ }^{1}$ lysimeters at Fort Keogh in 1994 and 1995.

\begin{tabular}{|c|c|c|c|c|c|}
\hline \multirow[b]{2}{*}{ Year } & \multirow[b]{2}{*}{ Date } & \multicolumn{2}{|c|}{ Pre-dawn ${ }^{2}$} & \multicolumn{2}{|c|}{ Mid-day $^{2}$} \\
\hline & & Pasm & Bogr & Pasm & Bogr \\
\hline 1994 & $\begin{array}{l}18 \mathrm{May} \\
31 \mathrm{May}^{3} \\
14 \mathrm{Jun}^{3} \\
23 \mathrm{Jun}^{3} \\
30 \mathrm{Jun}^{4} \\
13 \mathrm{Jul}^{4} \\
28 \mathrm{Jul}^{3}\end{array}$ & $\begin{array}{c}-0.32 \mathrm{~d} \\
-0.24 \mathrm{~d} \\
-0.44 \mathrm{~cd} \\
-0.75 \mathrm{~cd} \\
-4.18 \mathrm{a} \\
-1.04 \mathrm{bc} \\
-4.46 \mathrm{a}\end{array}$ & $\begin{array}{l}\text { Pa) }-\cdot-- \\
-0.42 \mathrm{~d} \\
-0.31 \mathrm{~d} \\
-0.20 \mathrm{~d} \\
-1.39 \mathrm{c} \\
-4.04 \mathrm{~b} \\
-4.92 \mathrm{a} \\
-5.00 \mathrm{a}\end{array}$ & $\begin{array}{c}-2.36 \mathrm{cde} \\
-2.81 \mathrm{bcd} \\
-3.62 \mathrm{ab} \\
-3.16 \mathrm{abc} \\
-2.90 \mathrm{bcd} \\
-4.00 \mathrm{a} \\
-3.15 \mathrm{abc}\end{array}$ & $\begin{array}{l}-0.62 \mathrm{e} \\
-2.12 \mathrm{~cd} \\
-2.69 \mathrm{bc} \\
-2.11 \mathrm{e} \\
-2.29 \mathrm{~cd} \\
-4.28 \mathrm{a} \\
-4.48 \mathrm{a}\end{array}$ \\
\hline 1995 & $\begin{array}{l}15 \text { May } \\
2 \text { Jun } \\
16 \text { Jun } \\
30 \mathrm{Jun}^{3} \\
17 \mathrm{Jul} \\
2 \mathrm{Aug}\end{array}$ & $\begin{array}{l}-0.43 \mathrm{~cd} \\
-0.99 \mathrm{bc} \\
-0.51 \mathrm{~cd} \\
-0.46 \mathrm{~cd} \\
-1.42 \mathrm{~b} \\
-3.88 \mathrm{a}\end{array}$ & $\begin{array}{l}-0.26 \mathrm{~d} \\
-0.59 \mathrm{~d} \\
-0.31 \mathrm{~d} \\
-0.50 \mathrm{~d} \\
-1.42 \mathrm{c} \\
-4.25 \mathrm{~b}\end{array}$ & $\begin{array}{c}-1.58 \mathrm{e} \\
-2.22 \mathrm{de} \\
-2.48 \mathrm{~cd} \\
-2.02 \mathrm{de} \\
-2.84 \mathrm{bcd} \\
-3.18 \mathrm{abc}\end{array}$ & $\begin{array}{c}-0.71 \mathrm{e} \\
-2.08 \mathrm{~cd} \\
-1.75 \mathrm{~d} \\
-0.70 \mathrm{e} \\
-2.62 \mathrm{bcd} \\
-3.30 \mathrm{~b}\end{array}$ \\
\hline
\end{tabular}

${ }_{2}^{1}$ There were no significant $(P \geq 0.10)$ differences in drought versus nondrought treatments.

${ }^{2}$ Means within columns with different letters are significantly different at $P \leq 0.05$.

${ }^{3}$ Significant $(\mathrm{P} \leq 0.05)$ mid-day species effects.

${ }^{4}$ Significant $(\mathrm{P} \leq 0.05)$ predawn species effects.

1994 and $94 \%$ (322 of 341) in 1995 of marked western wheatgrass tillers remained in a vegetative phenological stage during the growing seasons. On average, utilization was $49 \%$ and $51 \%$ for the first and second grazing events in 1994 and $53 \%$ and $46 \%$ for the first and second grazing events in 1995 . Over $90 \%$ of marked western wheatgrass tillers were grazed twice in 1994 and 1995.

\section{Tiller Relative Growth Rates}

Analyses of relative growth rates of twice-grazed blue grama tillers revealed significant $(\mathrm{P} \leq 0.01)$ treatment-by-time interactions (Fig. 2). Relative growth rates were reduced $(\mathrm{P}=0.01) 29 \%$ by drought before grazing treatments were imposed (i.e., May) but not different $(P \geq 0.30)$ from June through October in 1994 (Fig. 2 ). Growth rates of defoliated tillers were $107 \%$ greater $(P \geq 0.01)$ than undefoliated tillers after the first grazing event (i.e., June $)$, but similar $(\mathrm{P}=0.08)$ thereafter and not different $(P \geq 0.10)$ from zero from July through October (Fig. 2).

The year following the imposed drought (i.e., 1995), the blue grama time-bydrought $(P=0.02)$ and time-by-grazing treatment interactions were significant $(\mathrm{P}$ $\leq 0.01)$. In May, relative regrowth rates were $18 \%$ greater $(\mathrm{P}=0.01)$ for plants exposed to the imposed 1994 drought than for non-drought plants, but rates were similar $(P \geq 0.30)$ thereafter (Fig. 2). Relative growth rates in the ungrazed treatment during May 1995 were $19 \%$ greater $(\mathrm{P}=$ $0.02)$ than in either grazing treatment. However, following the first grazing event grazed (G94-95) than the 2 ungrazed (G94 and ungrazed) treatments in June, and declined through the season (Fig. 3).

\section{Tiller Recruitment}

The percent of primary blue grama tillers which produced an axillary tiller, varied during the 1994 growing season in response to drought and grazing (Table 2). Drought reduced $(\mathrm{P} \leq 0.01)$ total recruitment $80 \%$, whereas grazing increased $(\mathrm{P} \leq$ 0.01 ) recruitment $315 \%$ compared to ungrazed treatments. Sixty percent of daughter tillers were produced after the first grazing event. Of those producing axillary tillers, none in the drought treatment produced more than 1 axillary tiller. Eighteen percent in the non-drought treatment produced 2 secondary tillers.

In 1995, the magnitude of recruitment by blue grama was similar $(P=0.16)$ between drought and non-drought treatments (Table 2). Tiller recruitment for combined grazing treatments was $78 \%$ greater $(\mathrm{P} \leq 0.01)$ than without grazing. Ninety-eight percent of the tiller recruitment occurred after the first grazing event. On average, $30 \%$ of the blue grama tillers producing axillary tillers produced $2 \mathrm{sec}$ ondary tillers. It appeared that the seasonal pattern of axillary tillering by blue grama was similar in 1994 and 1995.

Recruitment by western wheatgrass tillers grazed twice also varied in magnitude between the 1994 drought and grazing treatments (Table 2). Drought reduced $(\mathrm{P} \leq 0.01)$ recruitment $91 \%$ (Table 2$)$. Grazed tillers exhibited greater $(\mathrm{P}=0.04)$ recruitment compared to ungrazed tillers (Table 2). More than $95 \%$ of the recruitment occurred in the fall (September and October) of 1994. No tillers in drought plots recruited more than 1 tiller. In contrast, of the primary western wheatgrass grass in 1995 in that relative growth rates were unaffected by drought treatment $(\mathrm{P}=$ $0.69)$, were greater $(P \leq 0.01)$ in the

Table 2. Least square means (\%), SE and P-values proportions of marked primary tillers that produced at least 1 axillary tiller during the growing season for blue grama and western wheatgrass subjected to drought and grazing treatments.

\begin{tabular}{|c|c|c|c|c|c|c|c|c|c|c|}
\hline \multirow[t]{2}{*}{ Year } & \multicolumn{4}{|c|}{ Drought Treatments ${ }^{1}$} & \multicolumn{4}{|c|}{ 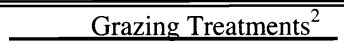 } & \multirow[b]{2}{*}{ P } & \multirow[b]{2}{*}{$\mathrm{D}^{*} \mathrm{G}^{3}$} \\
\hline & $\mathrm{D}$ & ND & $\mathrm{SE}$ & $\bar{P}$ & $\overline{\text { G94 }}$ & G94-95 & UG & $\mathrm{SE}$ & & \\
\hline \multicolumn{11}{|c|}{ Blue Grama $^{4}$} \\
\hline 1994 & $8 \mathrm{a}$ & $40 \mathrm{~b}$ & $\begin{array}{c}\%) \\
3\end{array}$ & $\leq 0.01$ & $31 \mathrm{a}$ & $32 a$ & $\begin{array}{l}\text { b) }-- \\
10 \mathrm{~b}\end{array}$ & $\begin{array}{r}- \\
3\end{array}$ & $\leq 0.01$ & 0.08 \\
\hline 1995 & 39 & 49 & 4 & 0.16 & $47 \mathrm{a}$ & $60 a$ & $30 \mathrm{~b}$ & 5 & 0.01 & 0.50 \\
\hline \multicolumn{11}{|c|}{ Western Wheatgrass ${ }^{4}$} \\
\hline 1994 & $7 \mathrm{a}$ & $79 b$ & 3 & $\leq 0.01$ & $47 \mathrm{a}$ & $46 a$ & $35 b$ & 3 & 0.04 & 0.07 \\
\hline 1995 & 6 & 11 & 3 & 0.18 & 5 & 15 & 6 & 3 & 0.12 & 0.84 \\
\hline
\end{tabular}

$\mathrm{D}=$ Drought, $\mathrm{ND}=$ Non Drought.

${ }^{2} \mathrm{G} 94=$ Grazed in 1994, G94-95 = Grazed in 1994 and 1995, UG = Ungrazed.

${ }^{3} \mathrm{D}^{*} \mathrm{G}=$ Drought by grazing interaction P-value.

${ }^{4}$ Drought or grazing treatment means in the same year (row), with different letters are significantly different at $\mathrm{P} \leq$ 0.05 . 

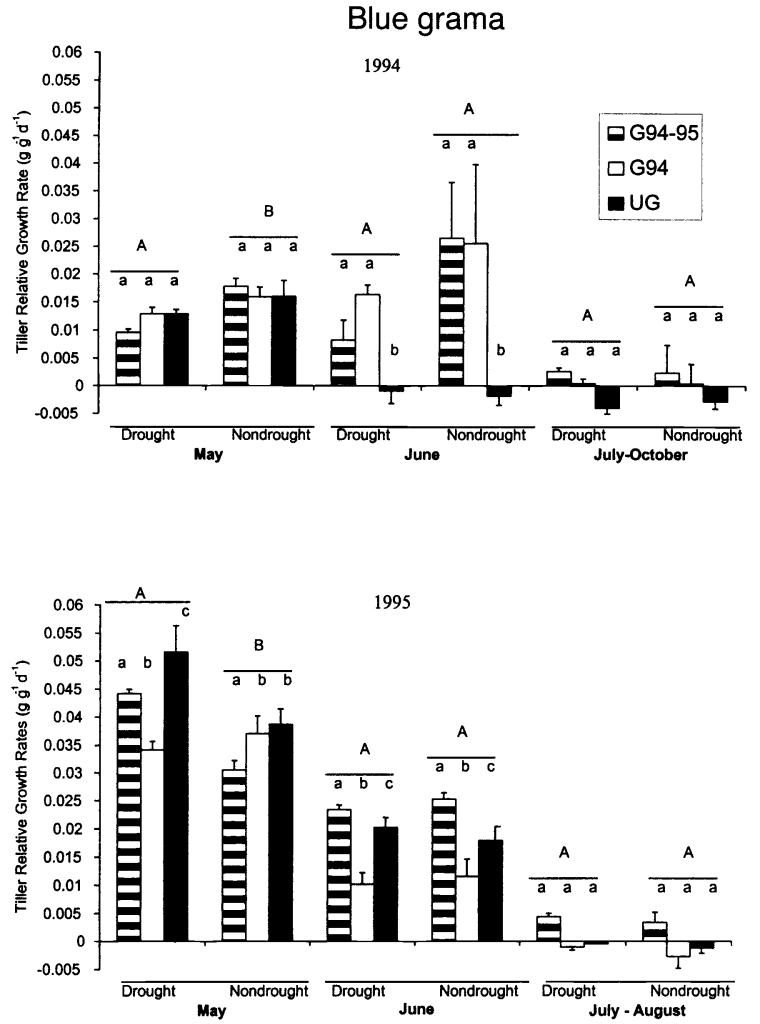

Fig. 2. Mean tiller relative growth rates $\left(\mathrm{g} \mathrm{g}^{-1} \mathrm{day}^{-1}\right)$ for blue grama in response to drought and grazing. Grazing treatments were grazed during and after drought (G94-95), grazed during drought and ungrazed after drought (G94), and ungrazed during and after drought (UG). Different capital letters (A and B) denote significant $(P \leq 0.05)$ differences between drought and nondrought within the same monthly period. Small letters $(a, b$ and $c)$ denote significant $(P$ $\leq 0.05)$ differences between grazing treatments within the same monthly period.

tillers producing axillary tillers in nondrought plants, $11 \%$ produced 2 daughter tillers. Eighty percent of the axillary tillers were produced in September through October in 1994.

Tiller recruitment by western wheatgrass during the growing season was similar between drought $(\mathrm{P}=0.18)$ and among grazing $(\mathrm{P}=0.12)$ treatments in 1995 (Table 2). Only $26 \%$ of the western wheatgrass tillers were recruited in the fall (September-October) of 1995. No western wheatgrass tillers produced more than 1 daughter tiller in 1995.

\section{Tiller Density}

Estimated pre-treatment tiller densities of blue grama were greater $(\mathrm{P}=0.06)$ in 1994 in drought compared to non-drought lysimeters $\left(8,646\right.$ vs. 9,854 tillers $\left./ \mathrm{m}^{2}\right)$ but not $(\mathrm{P} \geq 0.60)$ among grazing treatment lysimeters in 1994. Initial tiller densities were included as covariates for the 1995 and 1996 analyses. Tiller densities of blue
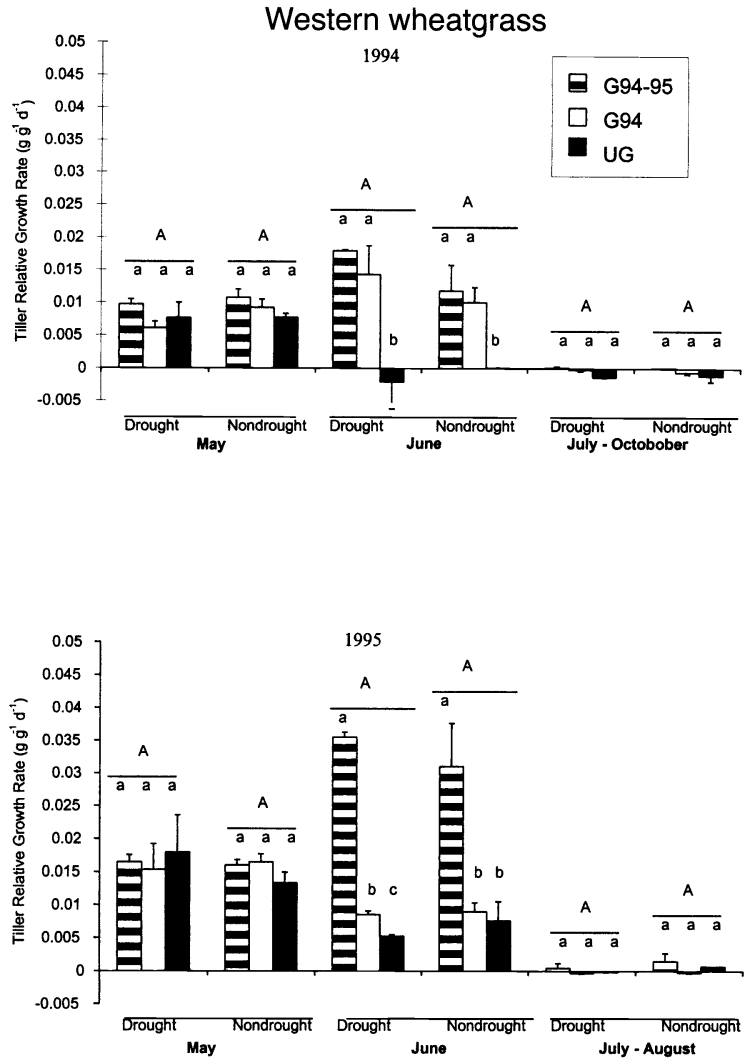

Fig. 3. Mean tiller relative growth rates $\left(\mathrm{g} \mathrm{g}^{-1} \mathrm{day}^{-1}\right)$ for western wheatgrass in response to drought and grazing. Grazing treatments were grazed during and after drought (G94-95), grazed during drought and ungrazed after drought (G94), and ungrazed during and after drought (UG). Different capital letters (A and $B$ ) denote significant $(P \leq 0.05)$ differences between drought and nondrought within the same monthly period. Small letters $(a, b$ and $c)$ denote significant $(P \leq 0.05)$ differences between grazing treatments within the same monthly period. grama were not $(\mathrm{P}=0.10)$ affected by drought in 1995 (8,068 vs. 9,420 tillers $\left.\mathrm{m}^{-2}\right)$, but in 1996, 2 years after the drought was imposed, tiller densities of blue grama stands subjected to drought were $59 \%$ greater $(\mathrm{P}=0.02)$ than not subject to drought $\left(9,967\right.$ vs. 6,263 tillers $\left.\mathrm{m}^{-2}\right)$. Grazing did not $(\mathrm{P}=0.49)$ affect densities in 1995 or 1996 . No significant $(P \geq 0.20)$ drought-by-tiller interactions occurred either year.

Initial (1994) tiller densities of western wheatgrass were different $(P \geq 0.01)$ and their covariates were significant $(P \geq 0.04)$ in 1995 but not $(P \geq 0.12)$ in 1996. Tiller densities were not $(\mathrm{P}=0.71)$ affected by drought in 1995 but were reduced $42 \%$ (P $=0.007)$ in 1996 (476 vs. 814 tillers $\mathrm{m}^{-2}$ ) when compared to non-drought treatments. Tiller densities were not affected ( $P$ $=0.49$ ) by grazing treatment or drought by grazing treatment $(P \geq 0.52)$ interactions in 1995 or 1996.

\section{Aboveground Net Primary \\ Production (ANPP)}

Blue grama production averaged $551 \mathrm{~kg}$ $\mathrm{ha}^{-1}$ across years and grazing treatments (Table 3). Pre-treatment ANPP for blue grama (i.e., 1993) did not differ $(\mathrm{P}=0.11)$ between drought treatments, but it was greater $(P=0.03)$ in the 2 grazed treatment plots than the ungrazed (Table 3 ). Analyses for years 1994 through 1996 showed all drought and grazing treatment effects were non-significant $(P \geq 0.10)$. Drought-by-grazing treatment interactions were not significant $(P \geq 0.10)$ in any year.

Estimated 1993 ANPP for western wheatgrass did not differ $(P=0.10)$ between drought treatment plots, but was greater $(P=0.05)$ in the $\mathrm{G} 94-95$ and ungrazed treatment plots than the G94 treatment plots (Table 3). Pre-treatment ANPP were not significant $(P \geq 0.22)$ covariates in any initial analyses, therefore, they were not included in the final analysis. Aboveground net primary pro- 
Table 3. Least square means $\left(\mathrm{kg} \mathrm{ha}^{-1}\right), \mathrm{SE}$, and $\mathrm{P}$-values for aboveground net primary production estimates for blue grama and western wheatgrass subjected to drought and grazing treatments.

\begin{tabular}{|c|c|c|c|c|c|c|c|c|c|c|}
\hline \multirow[t]{2}{*}{ Year } & \multicolumn{3}{|c|}{ Drought Treatments $^{1}$} & \multicolumn{6}{|c|}{ Grazing Treatments $^{2}$} & \multirow[b]{2}{*}{$\mathrm{D}^{*} \mathrm{G}^{3}$} \\
\hline & $\mathrm{D}$ & ND & SE & $\mathrm{P}$ & G94 & G94-95 & UG & SE & $\mathrm{P}$ & \\
\hline Blue Grama ${ }^{4}$ & \multicolumn{4}{|c|}{$\ldots \ldots\left(\mathrm{kg} \mathrm{ha}^{-1}\right) \ldots \ldots$} & \multicolumn{5}{|c|}{$\ldots \ldots-\ldots\left(\mathrm{kg} \mathrm{ha}^{-1}\right) \ldots \ldots$} & \\
\hline 1993 & 1,473 & 1,276 & 78 & 0.11 & $1,421 \mathrm{a}$ & $1,588 \mathrm{a}$ & $1,101 b$ & 96 & 0.03 & 0.14 \\
\hline 1994 & 712 & 639 & 90 & 0.58 & 680 & 566 & 781 & 110 & 0.43 & 0.10 \\
\hline 1995 & 564 & 476 & 81 & 0.47 & 562 & 334 & 663 & 99 & 0.13 & 0.48 \\
\hline 1996 & 516 & 398 & 64 & 0.24 & 395 & 357 & 619 & 78 & 0.10 & 0.90 \\
\hline \multicolumn{11}{|c|}{ Western Wheatgrass ${ }^{4}$} \\
\hline 1993 & 1,117 & 1,687 & 211 & 0.10 & $1,138 \mathrm{a}$ & $1,595 b$ & $1,472 b$ & 259 & 0.05 & 0.49 \\
\hline 1994 & $649 a$ & $1,277 \mathrm{~b}$ & 90 & $\leq 0.01$ & $757 \mathrm{a}$ & $756 a$ & $1,378 b$ & 110 & 0.01 & 0.98 \\
\hline 1995 & 978 & 1,376 & 129 & 0.07 & $1,608 \mathrm{a}$ & $481 b$ & $1,442 \mathrm{a}$ & 158 & $\leq 0.01$ & 0.17 \\
\hline 1996 & 961 & 1,347 & 166 & 0.15 & 1,275 & 1,029 & 1,157 & 204 & 0.70 & 0.40 \\
\hline
\end{tabular}

${ }^{1} \mathrm{D}=$ Drought, $\mathrm{ND}=$ Non Drought.

${ }^{2}$ G94 = Grazed in 1994, G94-95 = Grazed in 1994 and 1995, UG = Ungrazed

${ }^{3} \mathrm{D} * \mathrm{G}=$ Drought by grazing interaction P-value.

${ }^{4}$ Drought or grazing treatment means in the same year (rows), with different letters are significantly different at $\mathrm{P} \leq 0.05$.

duction was less $(\mathrm{P}=0.01)$ in the drought than non-drought treatment in 1994 and greater $(\mathrm{P}=0.01)$ in the ungrazed than grazed treatments (G94-95) in 1994. The only difference found thereafter, was that ANPP in G94-95 (which was grazed in $1995)$ was less $(\mathrm{P} \leq 0.01)$ in 1995 than in the 2 non-grazed treatments in 1995 (NG and G94). There were no drought by grazing treatment interactions $(\mathrm{P} \geq 0.17)$ in any year.

\section{Discussion}

Based on the results of this study, we conclude that: 1) relative growth rates of tillers which were grazed twice, were largely unaffected by drought and seasonally enhanced by grazing (Fig. 2 and 3); 2) axillary tillering was impeded by drought during the growing season and enhanced by grazing (Table 2); 3) tiller densities were unaffected by drought or grazing; and 4) neither drought nor grazing affected blue grama ANPP whereas drought reduced western wheatgrass ANPP with mixed grazing treatment effects (Table 3 ).

The major effects of drought were expressed by a slight $(19 \%)$ reduction in tiller relative growth rates of blue grama in May 1994, a large reduction in tillering for western wheatgrass (91\%) and blue grama (80\%) during the growing season in 1994 , and a large reduction of ANPP for western wheatgrass. Growth and tillering are often reduced by water stress (Brown 1995). Zhang and Romo (1995) reported the number of emerging northern wheatgrass (Agropyron dasystachyum (Hook.) Scriton.) tillers was positively correlated with soil water. Haferkamp et al. (1997 and 1998), Haferkamp and Heitschmidt
(1999) and Rummell (1946) reported western wheatgrass tiller density increased with the removal of competition of Japanese brome (Bromus japonicus Thunb.).

The responses to the initiation of the drought began to appear early in 1994 as shown by the change in blue grama tiller relative growth rates and the lack of a significant date-by-treatment interaction for western wheatgrass tiller relative growth rates. However, the response to the imposed drought and control lysimeters were similar due to the natural droughtlike conditions which existed during 1994. Precipitation was $24 \%$ below average, and this drought caused plants to be equally water stressed by May 1994 regardless of drought treatment (Table 1). This conclusion is also supported by the precipitation (Fig. 1), xylem water potentials, and soil water data reported previously by Heitschmidt et al. (1999).

Our results also suggest the effects of a 1 -year drought on growth rates did not carry over to the next year. Carry over effects may have been limited by the initial drought as well as above average precipitation that fell in March, April, and May 1995. Busso and Richards (1995) and Busso et al. (1989) did not find the effects of a 1-year drought on numbers of active axillary buds carried over to the next year. Only after 3 consecutive years of drought did Busso et al. (1989) find reduced numbers of metabolically active axillary buds.

Fewer axillary tillers were produced by western wheatgrass in 1995 than in 1994. Increased western wheatgrass tillering is associated with increased fall precipitation the previous year (Haferkamp et al. 1997). However, in this instance, the fall of 1994 was wetter than fall of 1993 (Fig. 1). Thus, the reduction of tillering in 1995 was more likely due to the dry summer of 1994 .

Grazing had little long-term effect on blue grama or western wheatgrass. The increase in tiller recruitment with grazing during the growing season agrees with findings of Sims et al. (1973). They reported mowing blue grama plants in late June and early July stimulated additional tillering, mostly from reproductive shoots that had elevated above the mowed height. Mowing earlier in the growing season depressed tillering, whereas mowing in late July and early August stimulated tillering, but insufficient growing season remained for complete development of these late tillers. They also reported increased tillering with mowing for sand bluestem (Andropogon hallii Hack.) a rhizomatous warm-season grass.

Our findings that grazing did not reduce ANPP of blue grama, but did decrease ANPP of western wheatgrass can best be explained by the different morphologies of the 2 species. Grass species like blue grama are characterized by short growing shoots and when grazed, these species can maintain much higher proportions of photosynthetic tissue than can species with long shoots like western wheatgrass (Dahl and Hyder 1977). Klipple and Costello (1960) noted that herbage production of western wheatgrass remained the same when utilization of that species increased from about $10 \%$ to about $20 \%$ but declined sharply when utilization increased to $40 \%$. Launchbaugh (1967) found that forage production of western wheatgrass declined as utilization increased from 44 to $80 \%$. Reed and Peterson (1961), Everson (1966), and Branson (1953) concluded that forage production of western wheatgrass declined with increased utilization. 
Many studies have shown the importance of environmental factors on production of mixed-grass rangelands (Coupland 1958, Reed and Peterson 1961, Hyder et al. 1975). Extended drought usually shifts species composition toward short grasses (Smoliak et al. 1972), but species composition shifts toward mid grasses when precipitation is above average (White et al. 1978). Shifts in plant species composition in this study were not observed (Heitschmidt et al. 1999). This lack of change in species composition may have been due to the timing and severity of the imposed drought. We failed to detect an increase in warm-season herbage production as reported by Heitschmidt et al. (1999), but our findings were probably due to slightly different methodologies.

\section{Management Implications}

Our results demonstrate a 1-year growing season drought combined with grazing (both during and after drought) did not appear to adversely affect tiller processes. Elimination of livestock grazing during or after a 1-year growing season drought may not be necessary to maintain plant populations on the tiller level for blue grama and western wheatgrass. Moderate stocking levels (40-50\% utilization) during and after drought did not adversely affect sustainability of dominant native grasses on these Northern Great Plains rangelands within the conditions of this study.

\section{Literature Cited}

Branson, R.A. 1953. Two new factors affecting resistance of grasses to grazing $\mathrm{J}$. Range Manage. 6:165-71.

Brown, R.W. 1995. The water relations of range plants, p. 291-413. In: D.J. Bedunah and R.E Sosebee (eds.) Wildland plants: Physiological ecology and developmental morphology. Soc. Range Manage. Denver, Colo.

Bullock, J.M., B. Clear Hill and J. Silvertown. 1994. Tiller dynamics of two grasses-responses to grazing, density and weather. J. Ecol. 82:331-340.

Burkhardt, J.W. 1996. Herbivory in the Intermountain West. Idaho Forest, Wildl. Range Exp. Sta. Bull. 58, Moscow, Ida.

Busso, C.A. 1988. Factors affecting recovery from defoliation during drought in two aridland tussock grasses. Ph.D. Thesis, Utah State Univ. Logan, Ut.

Busso, C.A. and J.H. Richards. 1993. Leaf extension rate in two tussock grasses: Effects of water stress and clipping. Oecologia. 14:3-15.
Busso, C.A. and J.H. Richards. 1995. Drought and clipping effects of tiller demography and growth of two tussock grasses in Utah. J Arid. Environ. 29:239-251.

Busso, C.A., R.J. Mueller and J.H. Richards. 1989. Effects of drought and defoliation on bud viability in two caespitose grasses. Ann. of Bot. 63:477-485.

Busso, C.A., J.H. Richards and N.J. Chatterton. 1990. Nonstructural carbohydrates and spring regrowth of two cool-season grasses: interaction of drought and clipping. J. Range Manage. 43:336-343.

Campbell, R.S. 1936. Climatic fluctuations, p.135-150. In: The Western Range. US Govt. Printing Office. Washington D.C.

Coupland, R.T. 1958. The effects of fluctuations in weather upon the grassland of the great plains. Bot. Rev. 24:274-312.

Dahl, B.E. and D.N. Hyder. 1977. Developmental morphology and management implications, p. 257-290. In: R.E. Sosebee (ed.) Rangeland plant physiology. Range Science Series No. 4. Soc. Range Manage. Denver, Colo.

Everson, A.C. 1966. Effects of frequent clipping at different stubble heights on western wheatgrass (Agropyron smithii, Rydb). Agron. J. 58:33-35.

Frank, A.B. and R.E Ries. 1990. Effects of soil water, nitrogen, and growing degreedays on morphological development of crested and western wheatgrass. J. Range. Manage. 43:257-260.

Haferkamp, M.R. and R.K. Heitschmidt. 1999. Japanese brome impacts on western wheatgrass in Northern Great Plains rangelands: An update. Great Plains Research 9:315-327.

Haferkamp, M.R., R.K. Heitschmidt, and M.G. Karl. 1997. Influence of Japanese brome on western wheatgrass yield. J. Range Manage. 50:44-50.

Haferkamp, M.R., R.K. Heitschmidt, and M.G. Karl. 1998. Clipping and Japanese brome reduce western wheatgrass standing crop. J. Range Manage. 51:692-698.

Heitschmidt, R.K., M.R. Haferkamp, M.G. Karl, and A.L. Hild. 1999. Drought and grazing: I. Effects on quantity of forage produced. J. Range Manage. 52:440-446.

Hulbert, S.H. 1984. Pseudoreplication and the design of ecological field experiments. Ecological Monographs 54:187-211.

Hyder, D.N., R.E. Bement, E.E. Remmenga, and D.F. Hervey. 1975. Ecological responses of native plants and guidelines for management of shortgrass range. ARS-USDA. Washington, D.C.

Klipple, G.E. and D.F. Costello. 1960. Vegetation and cattle responses to different intensities of grazing on shortgrass ranges on the Central Great Plains. USDA. Tech. Bull. 1216.

Kuchler, A.W. 1964. Potential natural vegetation of the conterminous United States. Amer. Geog. Soc. Spec. Pub. 36. Amer. Geog. Soc. N.Y.

Launchbaugh, J.L. 1967. Vegetation relationships associated with intensity of summer grazing on a clay upland range site in the Kansas 20- to 24-inch precipitation zone.
Kansas Agr. Exp. Sta. Tech. Bull. 154. Manhattan, Kans.

Ludlow, M.M. 1986. Simultaneous pressure of water stress and defoliation in rangeland plants, p. 433-436. In: P.J. Joss, P.W. Lynch and O.B. Williams (ed.), Proc. Symp. Rangelands: A resource under siege, $2^{\text {nd }}$ Int. Rangeland Congress. Cambridge, England.

National Oceanic and Atmospheric Administration. 1996. Climatological data, Montana annual summary. Nat. Climatol. Data Center, Asheville, N.C.

NeSmith, D.S. and J.T. Ritchie. 1992. Shortand long-term responses of corn to a preanthesis soil water deficit. Agron. J. 84:107-113.

Olson, B.E. and J.H. Richards. 1988. Annual replacement of the tillers of Agropyron desertorum following grazing. Oecologia. 76:1-6.

Pieper, R.D. and R.K. Heitschmidt. 1988. Is short-duration grazing the answer? J. Soil Water Conserv. 43(2):133-137.

Radford, P.J. 1967. Growth analysis formulae - their use and abuse. Crop Sci. 7:171-175.

Reed, M.J. and R.A. Peterson. 1961. Vegetation, soils, and cattle responses to grazing on northern Great Plains range. USDA For. Serv. Tech. Bull. \#1252.

Richards, J.H., M.M. Caldwell, and B.E. Olson. 1987. Plant production following grazing: carbohydrates, meristems and tiller survival over winter. Soc. Range Manage. Symposium. Boise, Ida.

Rummel, R.S. 1946. Some effects of competition from cheatgrass brome on crested wheatgrass and bluestem wheatgrass. Ecol. 27:159-167.

Scholander, P.F., H.T. Hammel, E.D. Bradstreet, and E.A. Hemmingsen. 1965. Sap pressure in vascular plants. Science 148:339-346

Sims, P.L., R.K. Lang'at, and D.N. Hyder. 1973. Developmental morphology of blue grama and sand bluestem. J. Range Manage. 26:340-344.

Smoliak, S., J.F. Dormaar, and A. Johnston. 1972. Long-term grazing effects on StipaBouteloua prairie soils. J. Range Manage. 25:246-250.

Tusler, C.A. 1993. Livestock defoliation patterns on native range under season-long and spring deferred grazing. M.S. Thesis. South Dakota State University, Brookings, S.D.

USDA Agricultural Statistics. 1993. Agricultural statistics. Nat. Agr. Statistics Ser. Washington, D.C.

White, L.M., J.J. Newbauer III, and J.R. Wight. 1978. Vegetational differences in native range during 38 years in eastern Montana, p. 260-262. In: D.N. Hyder (ed.) Proc. First Internat. Range Cong. Soc for Range Manage. Denver, Colo.

Willms, W.D. and P.G. Jefferson. 1993. Production characteristics of the mixed prairie: constraints and potential. Can. J. Anim Sci. 73:765-778.

Zhang, J. and J.T. Romo. 1995. Impacts of defoliation on tiller production and survival in northern wheatgrass. J. Range Manage. 48:115-120. 